\title{
Optimization of CCT Equations Using Calculated Grain Boundary Soluble Compositions for the Simulation of Austenite Decomposition of Steels
}

\author{
JYRKI MIETTINEN, SAMI KOSKENNISKA, MAHESH SOMANI, \\ SEPPO LOUHENKILPI, AARNE POHJONEN, JARI LARKIOLA, and JUKKA KÖMI
}

\begin{abstract}
New CCT equations have been developed and optimized to simulate the start temperatures of the austenite decomposition process in low-alloyed steels using experimental CCT data published in the literature. Exceptionally, this optimization does not apply the nominal compositions of the steels, but the corresponding soluble compositions of the grain boundaries calculated using IDS software, depending on the reported austenitization treatments of the steels. These compositions, rather than the nominal ones, are expected to control the start of the austenite decomposition, which usually initiates at the grain boundaries. The new optimization treatment takes into account the solute microsegregation and the possible precipitate formation. Using IDS software, the new equations were validated with new experimental CCT data. Agreement was good not only for the austenite decomposition start temperatures, but also for the final phase fractions, indicating fairly reasonable predictions of phase transformation kinetics by the IDS. In addition, IDS simulations were compared with the experimental CCT data of five high-carbon steels, applying both the new equations based on grain boundary soluble compositions as well as the equations based on the nominal compositions. With the same experimental CCT data used in optimization, better agreement was obtained with the new equations, indicating the importance of determining the soluble compositions at the grain boundaries where the austenite decomposition process is likely to begin.
\end{abstract}

https://doi.org/10.1007/s11663-019-01698-7

(C) The Author(s) 2019

\section{INTRODUCTION}

THE prediction of CCT diagrams based on steel compositions has been the subject of several earlier studies as described in references. ${ }^{[1-4]}$ Typically, these predictions are based on statistical analysis of measured CCT curves. Trzaska et al. proposed an artificial neural network method for the calculation of CCT diagrams based on steel composition. ${ }^{[1]}$ Kirkaldy et al. optimized

JYRKI MIETTINEN is with the Process Metallurgy Research Group, University of Oulu, P.O. Box 8000, 90014, Oulu, Finland. SAMI KOSKENNISKA, MAHESH SOMANI, AARNE POHJONEN, JARI LARKIOLA, and JUKKA KÖMI is with the Material and Mechanical Engineering, University of Oulu, P.O. Box 8000, 90014, Oulu, Finland. Contact e-mail: sami.koskenniska@oulu.fi SEPPO LOUHENKILPI is with the Process Metallurgy Research Group, University of Oulu and also with the Material and Mechanical Engineering, University of Oulu and also with the Department of Materials Science and Engineering, Aalto University, Vuorimiehentie 2, 02150 Espoo, Finland.

Manuscript submitted May 8, 2019.

Article published online October 1, 2019. their model parameters over experimental TTT diagrams in References 2 and 3. After optimization, the model can be used to calculate the CCT diagram applying the Scheil-Avrami or additivity rule. ${ }^{[5]}$ The same methodology is used in commercial software JMatPro. ${ }^{[4]}$

Since 1984, a thermodynamic-kinetic software package, IDS (InterDendritic Solidification), has been developed to simulate the phase change, compound formation/dissolution and solute distribution during the solidification of steels, and the subsequent cooling/ heating process after solidification. ${ }^{[6-8]}$ IDS can also be used as a sub-tool in online calculations of continuous casting by coupling it to a proper heat-transfer model of the process. ${ }^{[9]}$ In such a case, the impacts of the casting conditions are considered, by using the calculated nodal cooling rates of the strand as input data for IDS. The solid-state phase transformations related to the austenite decomposition process can also be simulated and predicted fairly accurately using an additional module called ADC. The ADC module is used for low-alloy steels in the temperature range of $900{ }^{\circ} \mathrm{C}$ to $25^{\circ} \mathrm{C}$ in order to simulate the decomposition of austenite into 
proeutectoid ferrite or cementite, pearlite, bainite, and also martensite. During the simulation, the formation or dissolution of different precipitates is included. The ADC module applies thermodynamic chemical potential equality equations of paraequilibrium condition, ${ }^{[10]}$ the material balance equations for the ferrite/austenite interface advancing in a spherical austenite grain ${ }^{[11]}$ (previously for carbon only, but later extended to nitrogen and boron as well), and the continuous cooling transformation (CCT) equations optimized from the measurements made in Germany ${ }^{[12,13]}$ and Great Britain. ${ }^{[14]}$ In these equations, the influencing solutes are $\mathrm{C}$, $\mathrm{Si}, \mathrm{Mn}, \mathrm{Cr}$, Mo, and Ni. The ADC module works reasonably well for typical low-alloyed steels, but its results are not as smooth as those of the more sophisticated software of JMatPro. ${ }^{[4]}$

In the ADC calculations, we assume that the austenite decomposition process starts at the grain boundaries where there are a great number of favorable nucleation sites due to the presence of precipitates and high dislocation density. Depending on the earlier cooling history, the solute concentration at the grain boundaries becomes quite different from the nominal steel composition. This is due to solute microsegregation and the formation of precipitates, tying up certain solutes from the grain boundary solid solution phase (austenite or ferrite). Assuming that these grain boundary compositions are identical to the interdendritic compositions, calculated with IDS at any temperature (also below the solidus), the ADC module can then consider these compositions as the start values of the simulation. These compositions, however, become identical only if the grain boundaries always meet the interdendritic regions, regardless of how many dendrite arms the grain can include. The real situation, of course, is never so ideal. Besides, all grain boundaries are not the same in character and energy. Nevertheless, using these assumptions, the real solidification history of the steel in terms of its microsegregation and precipitate formation are included in determining the CCT behavior. This has not been taken into account in earlier studies of the CCT diagram predictions. They normally apply nominal compositions, which is not precisely correct, because the grain boundary soluble composition is the main influential factor for phase transformations, and the precipitates may also have noticeable effects on phase nucleation.

However, there is a specific problem in the new treatment. As the CCT sources do not provide the grain boundary soluble compositions for the reader, we were forced to use the steel nominal compositions in our earlier optimized CCT equations. ${ }^{[6]}$ Consequently, the optimized parameters of these equations are only tentatively applicable in the ADC module. Therefore, it was necessary to develop new CCT equations, which apply the grain boundary soluble compositions instead of the nominal ones. For this purpose, a new calculation procedure, using the IDS software, is presented in this work. The new CCT equations, based on the CCT measurements/diagrams made in Germany ${ }^{[12,13]}$ and Great Britain, ${ }^{[14]}$ are given as well. Also presented in this study is the validation of these equations with the new experimental CCT measurements made for the present study. A comparison of the predictions made using the newly developed CCT equations based on the grain boundary composition and those developed previously based on nominal bulk composition has also been made, particularly with respect to the CCT measurements of high-carbon steels given in the literature. The results of the current study can also be complemented by the effect of thermomechanical processing $^{[15-18]}$ taking place in many steel processing operations. ${ }^{[19]}$ On the other hand, the current method using IDS to include the effect of deformation on phase transformations and precipitation is still quite approximate and needs to be developed further.

\section{METHOD}

The new method replaces the previously developed CCT equations ${ }^{[6]}$ that consider the nominal steel compositions with the new CCT equations applying the corresponding grain boundary soluble compositions. The procedure is illustrated in Figure 1. The first step is to use the IDS software to calculate the interdendritic soluble compositions for the steels of the German ${ }^{[12,13]}$ and British ${ }^{[14]}$ studies. These are calculated at the yellow spots (measured start temperatures) of Figure 1, marking the beginning of austenite decomposition, following the reheating and holding (blue) and subsequent cooling (violet) paths. The calculations are done for all the primary phases (proeutectoid ferrite, pearlite, bainite, and martensite) of the selected steels used in developing the empirical CCT equations.

The present treatment applies a constant cooling rate of $1{ }^{\circ} \mathrm{C} / \mathrm{s}$ for all steels at high temperatures, taking into account the effects of different holding treatments (blue horizontal line in Figure 1) reported individually for all CCT steels. The cooling rate of $1^{\circ} \mathrm{C} / \mathrm{s}$ was used as we do

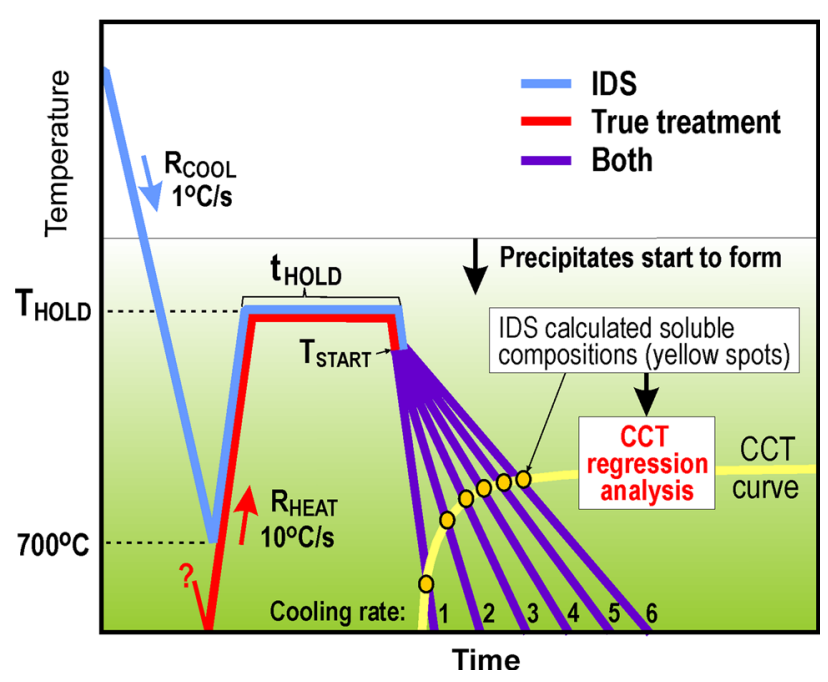

Fig. 1-Schematic drawing showing the steps of IDS simulation (blue and violet lines) to calculate the soluble compositions for optimizing the CCT equation of austenite decomposition. Also shown in the figure are the steps of the actual treatment of the CCT experiments (red and violet lines) (Color figure online). 
not know the original rates applied for the steels. Some lower or higher rates, however, are not expected to affect the results very much, due to the dominating effect coming from the subsequent holding treatment. As depicted by blue heating/cooling profile in the figure, the steels are first allowed to cool down to $700{ }^{\circ} \mathrm{C}$, prior to reheating and holding. Even the simulation of austenite decomposition or dissolution around that temperature $\left(700{ }^{\circ} \mathrm{C}\right)$ has not been considered. In real experiments, the CCT steels have been cooled down to room temperature (not shown in Figure 1) followed by reheating to the holding temperature to homogenize the austenitic structure for a given duration (as depicted by the red line). Then, the samples are cooled along different linear cooling rates of the CCT experiments to determine the start temperatures of austenite decomposition. Hence, from the point of heating from about 700 ${ }^{\circ} \mathrm{C}$ until the completion of the CCT tests, the IDS simulation follows the real CCT treatment. However, before this point, the treatments can be different and varying, making the true soluble compositions differ from those calculated by the IDS. In spite of the possible variation, we strongly believe that the IDS-calculated soluble compositions are fairly close to those of the actual treatment. This is because all the CCT steels have first gone through a solidification process, leaving the structure in homogenous. Even the austenite decomposition (during cooling) and subsequent dissolution of the decomposition products back to austenite (during reheating) are largely ineffective in homogenizing the solute compositions, owing to the short duration of cooling and reheating and the poor solute diffusivities at such low temperatures.

On the other hand, the actual CCT treatments may sometimes include prior additional thermomechanical treatments such as hot and controlled rolling schedules leading to recrystallized or strained austenite matrices, respectively. In the case of cold rolling, no compositional changes are expected to take place. The hot-rolling process, however, may largely influence the grain boundary composition, particularly when the duration of thermomechanical treatment is long. Due to this, all the CCT steels, which had gone through effective hot-rolling processes leading to significant microstructural reconstitution, refinement, and also pancaking (straining), were not included in the optimization of the CCT equations.

For the CCT curves of the secondary austenite decomposition phases, such as pearlite after proeutectoid ferrite formation, bainite after pearlite formation, or martensite after bainite formation, the suggested method does not work so well. This is due to the fact that the IDS cannot calculate soluble compositions at the interface of the austenite and the primary decomposition phase, which would be needed for the optimization when the CCT phase is of the secondary type. The only way to do that would be to follow up the IDS simulation by ADC simulation. That, however, is somewhat difficult, because in the ADC module, we would need to use the same CCT equations that we are just trying to optimize. Another reason for ignoring the ADC simulation from the optimization concerns the calculated soluble compositions that could lead to a poor correlation in the equations. This is because the measured temperature values used in the optimization (yellow spots in Figure 1) are not necessarily located in the same phase regions as predicted by the ADC simulations. Consequently, we could get quite varying soluble composition values for the optimization, depending on which calculated phase region we are in. Therefore, for the secondary decomposition phases too, we calculate the soluble compositions using only the IDS. Again, these compositions correspond to the yellow spots of Figure 1, but now correspond to the measured temperature values of the secondary phase formation. It is evident that this approximation causes some uncertainty in the "secondary phase part" of the optimized CCT equation, and particularly, if a significant fraction of the primary phase has already formed before the manifestation of the secondary phase.

In spite of the simplifications made by applying the IDS-calculated soluble compositions in the CCT optimization, we can expect to get more realistic results using the new CCT equations based on the grain boundary soluble compositions rather than using the previously optimized equations applying the nominal steel compositions. This is particularly true not only for the primary decomposition phases, but also for the secondary phases, unless they form close to the completion of the austenite/primary phase transformation. It is to be noted that by employing the new CCT equations, the calculated start temperatures of any phase formation (in the ADC module) become fixed just before the start of the austenite decomposition process. During the decomposition process, these do not change, since the new CCT equations have been optimized using the soluble compositions calculated in the purely austenitic region only. Exceptionally, however, some CCT equations, when applied to calculate the temperature of the secondary phase formation, can still depend on the cooling history.

\section{EXPERIMENTAL MEASUREMENTS}

CCT dilatation measurements were made for steel A (composition shown in Table I) in a Gleeble 3800 simulator to construct the CCT diagram illustrating its constitutive austenite decomposition behavior at different linear cooling rates. Cylindrical specimens of dimensions $\varnothing 6 \times 9 \mathrm{~mm}$ were machine-cut from a hot-rolled plate, which was heat treated at $1250{ }^{\circ} \mathrm{C}$ for 2 hours to produce a homogenized composition. In Gleeble measurements, samples were heated at $10{ }^{\circ} \mathrm{C} / \mathrm{s}$ to $1200{ }^{\circ} \mathrm{C}$ and cooled at various rates in the range of $1-50{ }^{\circ} \mathrm{C} / \mathrm{s}$ to reveal the start of various phase transformation temperatures, as also verified through metallography. The final phase fractions were also estimated for these CCT samples, using images taken with a field emission scanning electron microscope (FESEM) Zeiss Sigma and a laser scanning confocal microscope Keyence VK-X200. The constructed CCT diagram is shown in Figure 2 and the measured values for the transformation temperatures and final phase fractions are tabulated in Table II. 
From the samples studied, the average secondary dendrite arm spacing (SDAS) and the average, minimum, and maximum manganese compositions $\left(\mathrm{C}_{\mathrm{Mn}}^{\text {ave }}\right.$, $\mathrm{C}_{\mathrm{Mn}}^{\min }$ and $\mathrm{C}_{\mathrm{Mn}}^{\max }$ ) were also determined, using the electron probe microanalyzer (EPMA) JEOL JXA-8200. The measured values are displayed in Table III, together with the values calculated with IDS. Note that the measured SDAS value is not accurate, as it was estimated by the observed distances between the minimum and maximum Mn compositions, assuming that these compositions correspond to the center and surface of the secondary dendrite arm. Note also that the measured average manganese content, $1.27 \mathrm{wt}$ pct, is higher than the reported nominal composition of 1.10 wt pct, applied in the IDS calculations. Consequently, the measured minimum and maximum $\mathrm{Mn}$ values are also higher compared to the calculated ones. Different manganese levels may be explained by systematic error in either device measurements or different compositions in altered measuring points. The segregation ratios of $\mathrm{C}_{\mathrm{Mn}}^{\min } / \mathrm{C}_{\mathrm{Mn}}^{\mathrm{ave}}$ and $\mathrm{C}_{\mathrm{Mn}}^{\max } / \mathrm{C}_{\mathrm{Mn}}^{\mathrm{ave}}$, however, are quite close to each other, indicating a similar tendency for $\mathrm{Mn}$ to segregate, both through the experimental measurements as well as the IDS calculations. This gives a good background for the present method, applying the interdendritic soluble compositions in optimizing the new CCT equations.

\section{EFFECT OF CARBIDES}

As stated in the introduction, the soluble interdendritic/grain boundary compositions are affected not only by the solute microsegregation, but also due to the formation of precipitates. Typical precipitates capable of tying up solutes from the solution in steels are sulfide $(\mathrm{Fe}, \mathrm{Mn}) \mathrm{S}$ and different carbides. The role of carbides becomes essential in high-carbon alloys, where they can drop the soluble compositions of $\mathrm{C}, \mathrm{Cr}$, and Mo to very low values. This of course has a great influence on the CCT equations to be optimized ("Optimized CCT Equations"). Therefore, we made an example simulation to illustrate the effects of carbides.

The results of this simulation are given in Table IV. It presents the IDS-calculated soluble compositions at 700 ${ }^{\circ} \mathrm{C}$ in four steels containing $0.5-2 \mathrm{wt}$ pet $\mathrm{C}, 0.5 \mathrm{wt}$ pet $\mathrm{Si}$, 1 wt pet $\mathrm{Mn}$, and 0.5 wt pet $\mathrm{Cr}$, with and without precipitation. Also shown is the temperature history of calculations and the calculated carbide amounts at 700 ${ }^{\circ} \mathrm{C}$. Let us first look at the calculated results of the alloy $\mathrm{C} 05$. The calculated $\mathrm{Si}, \mathrm{Mn}$, and $\mathrm{Cr}$ soluble compositions are about 40, 30, and 20 pct higher than the nominal ones, respectively. Increasing the final cooling rate from 0.01 to $5{ }^{\circ} \mathrm{C} / \mathrm{s}$ increases the soluble compositions only slightly, since the diffusion rates below the holding temperature $\left(1000{ }^{\circ} \mathrm{C}\right)$ are no longer appreciable. As no carbides formed during holding or cooling, the present results describe the microsegregation tendency of these solutes well, due to their finite diffusion rates in austenite. In the $\mathrm{C} 10$ alloy, the soluble composition of $\mathrm{Mn}$ is slightly lower and that of $\mathrm{Cr}$ somewhat higher in the absence of any precipitation. In a real case, 


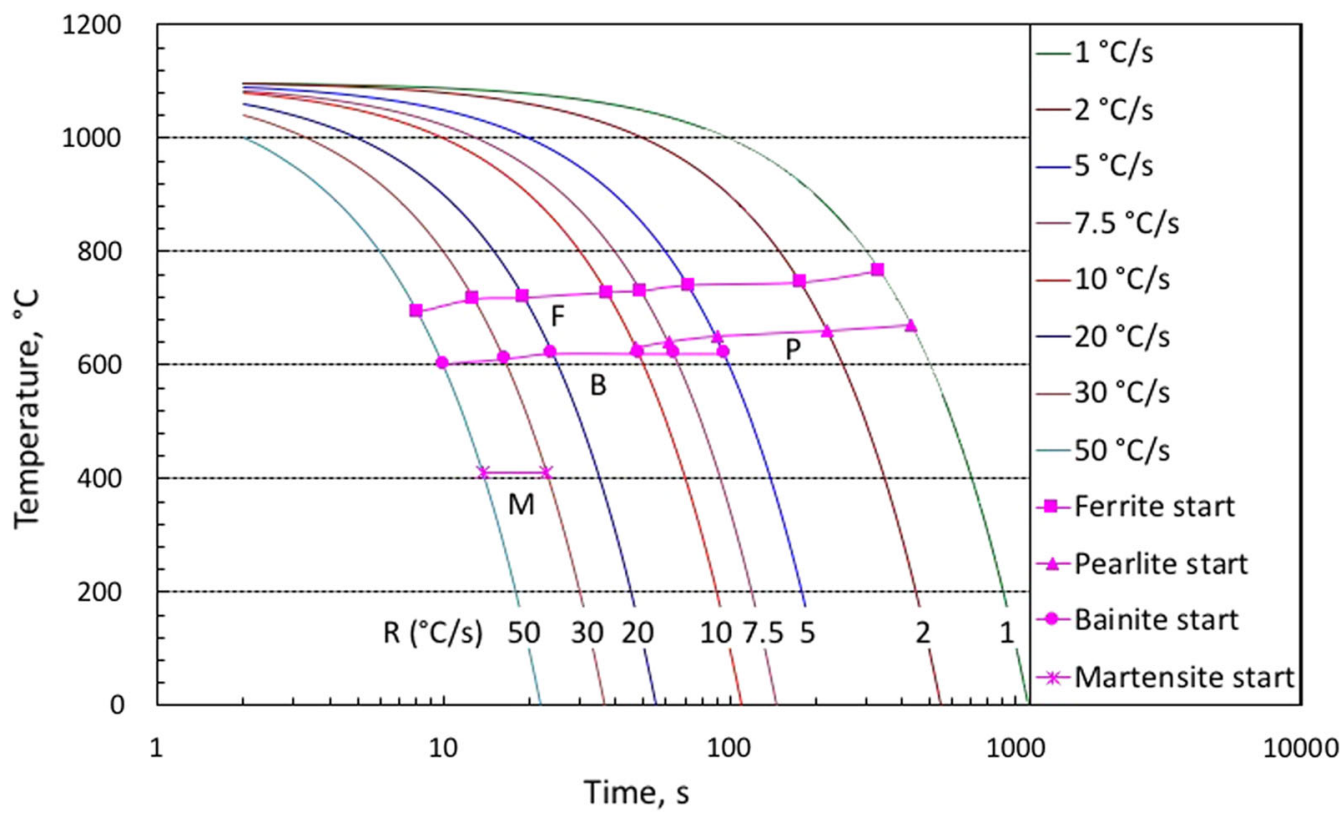

Fig. 2-Experimentally determined CCT curves of steel A.

Table II. Experimental Transformation Start Temperatures and Final Phase Fractions (Volume Percent) at $25^{\circ} \mathrm{C}$ for steel A

\begin{tabular}{|c|c|c|c|c|c|c|c|c|c|}
\hline No & $R\left({ }^{\circ} \mathrm{C} / \mathrm{s}\right)$ & $T^{\mathrm{F}}\left({ }^{\circ} \mathrm{C}\right)$ & $T^{\mathrm{P}}\left({ }^{\circ} \mathrm{C}\right)$ & $T^{\mathrm{B}}\left({ }^{\circ} \mathrm{C}\right)$ & $T^{\mathrm{M}}\left({ }^{\circ} \mathrm{C}\right)$ & $\mathrm{F}(\mathrm{Pct})$ & $\mathrm{P}(\mathrm{Pct})$ & $\mathrm{B}(\mathrm{Pct})$ & $\mathrm{M}(\mathrm{Pct})$ \\
\hline 1 & 1 & 765 & 670 & - & - & 70 & 30 & - & - \\
\hline 2 & 2 & 745 & 660 & - & - & 65 & 35 & - & - \\
\hline 3 & 5 & 740 & 650 & 620 & - & 55 & 15 & 30 & - \\
\hline 4 & 7.5 & 730 & 640 & 620 & - & 43 & 10 & 47 & - \\
\hline 5 & 10 & 727 & 630 & 620 & - & 39 & 6 & 55 & - \\
\hline 6 & 20 & 718 & 625 & 620 & - & 33 & 2 & 65 & - \\
\hline 7 & 30 & 715 & - & 610 & 410 & 15 & - & 55 & 30 \\
\hline 8 & 50 & 692 & - & 600 & 410 & 10 & - & 30 & 60 \\
\hline
\end{tabular}

F: proeutectoid ferrite, P: pearlite, B: bainite, M: martensite.

Table III. Measured Secondary Dendrite Arm Spacing (SDAS) and Mn Contents (Average, Minimum, and Maximum) in Steel A

\begin{tabular}{lcccccc}
\hline Method & SDAS $(\mu \mathrm{m})$ & $\mathrm{C}_{\mathrm{Mn}}^{\mathrm{ave}}($ Weight Percent) & $\mathrm{C}_{\mathrm{Mn}}^{\min }($ Weight Percent) & $\mathrm{C}_{\mathrm{Mn}}^{\max }($ Weight Percent) & $\mathrm{C}_{\mathrm{Mn}}^{\min } / \mathrm{C}_{\mathrm{Mn}}^{\mathrm{ave}}$ & $\mathrm{C}_{\mathrm{Mn}}^{\max } / \mathrm{C}_{\mathrm{Mn}}^{\mathrm{ave}}$ \\
\hline EPMA (Exp) & $160-200$ & 1.27 & 1.13 & 1.36 & 0.89 \\
IDS (Calc) & 180 & $1.10^{*}$ & 0.947 & 1.224 & 1.07 \\
\hline
\end{tabular}

Also included in the table are $\mathrm{C}_{\mathrm{Mn}}^{\min } / \mathrm{C}_{\mathrm{Mn}}^{\text {ave }}$ and $\mathrm{C}_{\mathrm{Mn}}^{\max } / \mathrm{C}_{\mathrm{Mn}}^{\text {ave }}$ ratios, together with the IDS-calculated $\mathrm{Mn}$ compositions and ratios (an average value of SDAS $=180 \mu \mathrm{m}$ was used in the calculations).

*Nominal composition reported by the steel supplier (measured by OES).

however, both soluble compositions are reduced due to carbide formation, i.e., those of cementite members of $(\mathrm{Fe}, \mathrm{Mn})_{3} \mathrm{C}$ and $(\mathrm{Fe}, \mathrm{Cr})_{3} \mathrm{C}$, and $(\mathrm{Cr}, \mathrm{Fe})_{7} \mathrm{C}_{3}$. The decrease in $\mathrm{Cr}$ content is far more significant than for $\mathrm{Mn}$, since $\mathrm{Cr}$ is effectively tied up in two carbides. Note also the slight consumption of $\mathrm{C}$ in these carbides (about 0.02 wt pct). It is noteworthy that no cementite is formed at the higher cooling rate of $\mathrm{R}_{\mathrm{FIN}}=5^{\circ} \mathrm{C} / \mathrm{s}$. This is due to its reduced kinetics. Consequently, the soluble $\mathrm{Mn}$ composition remains higher (1.24 wt pct) than obtained at the lower cooling rate of $\mathrm{R}_{\mathrm{FIN}}=0.01{ }^{\circ} \mathrm{C} / \mathrm{s} \quad(0.93$ wt pct). Instead, the soluble $\mathrm{Cr}$ composition becomes quite small at both cooling rates. This is due to the strong tendency of $\mathrm{Cr}$ to form two carbide types, $(\mathrm{Fe}, \mathrm{Cr})_{3} \mathrm{C}$ and $(\mathrm{Cr}, \mathrm{Fe})_{7} \mathrm{C}_{3}$.

In contrast to the above, in the case of alloy $\mathrm{C} 15$, we can see highly enhanced carbide formation, due to the higher $\mathrm{C}$ content of the steel. Again, the higher cooling rate of $\mathrm{R}_{\mathrm{FIN}}=5{ }^{\circ} \mathrm{C} / \mathrm{s}$ slightly suppressed the cementite formation due to reduced kinetics, thus increasing the 


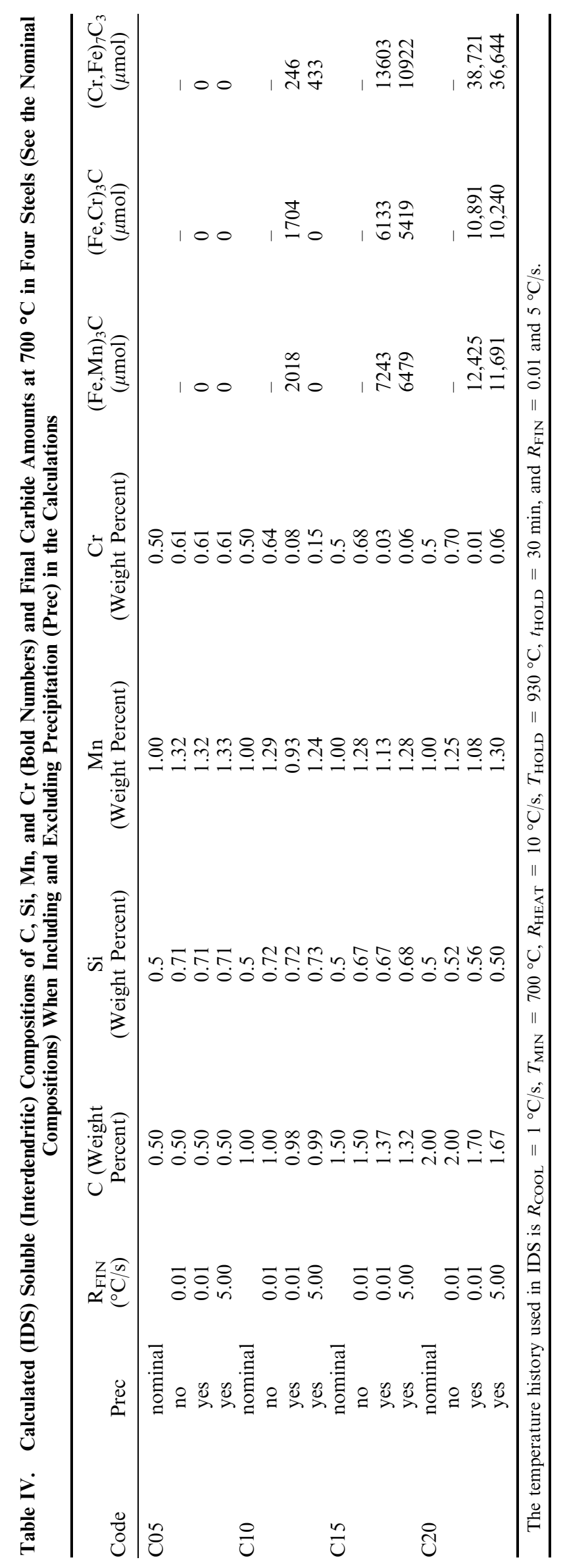


soluble composition of $\mathrm{Mn}$, whereas that of $\mathrm{Cr}$ is reduced due to the enhanced $(\mathrm{Cr}, \mathrm{Fe})_{7} \mathrm{C}_{3}$ formation. Note also the clearly higher carbon consumption in carbides, about $0.15 \mathrm{wt}$ pct. The explanations given for the $\mathrm{C} 15$ alloy are also valid for the $\mathrm{C} 20$ alloy, except that the carbide amounts are now appreciably higher. In this case, a large fraction of carbon (about 0.3 pct C) is consumed to tie up $\mathrm{Mn}$ and $\mathrm{Cr}$, not only in the interdendritic region, but also from the core of the dendrite. This can be concluded by the fact that the soluble compositions are practically at the same level as seen in the C15 alloy.

The results of these example calculations are, of course, highly dependent on the temperature history involved. Somewhat different results can be expected when changing or ignoring the present heating and/or holding treatment of the simulation. In addition, adding sulfur in these steels decreases the soluble Mn composition, by the formation of $(\mathrm{Fe}, \mathrm{Mn}) \mathrm{S}$, and adding molybdenum changes the soluble compositions in a more complex way, due to the formation of molybdenum carbides and their competitive growth with other carbides. Nevertheless, as they are able to form and dissolve during the cooling, heating, and holding processes, the carbides considered have a very important role in calculating the soluble compositions for the present optimization process.

The previous calculations are based on recent development work made in IDS to simulate carbide formation. A short validation of this work is given in the following. Six high-carbon steels of Reference 13 and seven high-carbon steels of Reference 20 were selected to compare their CCP-type (continuous cooling precipitation) carbide formation temperatures with those calculated using the IDS. In all of these cases, the initial structure was purely austenitic. Note that as the original data of Reference 20 was of the TTP type (time-temperature-precipitation), it was first converted to CCP form, using the additivity rule. ${ }^{[21]}$ The selected steels and the results of the calculations are presented in Table V, which shows the applied cooling rates $(R)$, the experimental and calculated temperature values of carbide formation ( $T_{\mathrm{EXP}}$ and $\left.T_{\mathrm{CAL}}\right)$, the differences of these temperatures $(\Delta T)$, and the primary carbides formed. The average error for the temperature difference $\Delta T$ is $16.5^{\circ} \mathrm{C}$. The agreement appears reasonable when taking into account the long process history before carbide formation and the moderate accuracy in measuring the first tiny carbide particles. As an additional validation, we used the IDS to calculate the carbide fractions in 23 high-carbon steels of Reference 13 using their reported two holding treatments of $30 \mathrm{~min}$ at $930^{\circ} \mathrm{C}$ and $15 \mathrm{~min}$ at $830{ }^{\circ} \mathrm{C}$. In most cases $(85 \mathrm{pct})$, the calculated precipitate fractions agreed with the observed ${ }^{[13]}$ presence of carbides. Even in the remaining 15 pct cases with moderate agreement, the error was small, as only small amounts of carbides formed, when none were observed or were about to form.

Simulating carbide formation by IDS (or its ADC module) is much more practical than applying the optimized CCT equation for carbide formation earlier integrated into the ADC module. ${ }^{[6]}$ That equation, even though validated by measurements of several steels, was misleading, as in most of these steels, carbides were present even at temperatures above the predicted CCT curves. In this case, the experimental curves did not describe the initiation of carbide formation from the austenite but mentioned only their enhanced formation from the austenite + carbide structure during the cooling following the homogenization treatment. Hence, in the present IDS or ADC simulations, the earlier optimized CCT curve has been replaced by the calculated curve of the most stable carbide forming during cooling.

\section{OPTIMIZED CCT EQUATIONS}

Using the CCT measurements of the German ${ }^{[12,13]}$ and British ${ }^{[14]}$ studies on low-alloyed steels, by applying the IDS-calculated interdendritic soluble compositions for these steels, the following equations were optimized to calculate the start temperatures of different phase formations during the austenite decomposition process:

$$
T^{\phi}=a_{1}+\sum_{i=2}^{7} a_{i} C_{i}+\sum_{i=2}^{7} \sum_{j=i}^{7} b_{i j} C_{i} C_{j}+c_{1} R+c_{2} \ln (R)+c_{3} P_{A}
$$

$$
\log \left(R^{\phi}\right)=a_{1}+\sum_{i=2}^{7} a_{i} C_{i}+\sum_{i=2}^{7} \sum_{j=i}^{7} b_{i j} C_{i} C_{j}+c_{3} P_{A} .
$$

Here, $T^{\phi}\left({ }^{\circ} \mathrm{C}\right)$ is a phase formation temperature, $R^{\phi}$ $\left({ }^{\circ} \mathrm{C} / \mathrm{s}\right)$ is a critical cooling rate of phase formation, $a_{i}$, $b_{i j}$, and $c_{k}$ are parameters to be solved by regression analysis, $C_{i}$ (wt pct) is the interdendritic soluble composition of solute $i(i=\mathrm{C}, \mathrm{Si}, \mathrm{Mn}, \mathrm{Cr}, \mathrm{Mo}$, and $\mathrm{Ni}$, with $i=2-7$, while solvent $\mathrm{Fe}$ is denoted by $i=1$ ), $\mathrm{R}$ $\left({ }^{\circ} \mathrm{C} / \mathrm{s}\right)$ is the cooling rate between $800{ }^{\circ} \mathrm{C}$ and $500{ }^{\circ} \mathrm{C}$, and $P_{\mathrm{A}}$ is a parameter related to the austenitization treatment. ${ }^{[22]}$ It is worth noting that Eqs. [1] and [2] are independent of the phase transformation kinetics as they were optimized using the interdendritic soluble composition of austenite only. Also note that at very low cooling rates the value of temperature $T^{\phi}$ may sometimes exceed its equilibrium value, such as the Ae3 temperature, when considering ferrite formation. In such a case, its value was fixed to the equilibrium value.

Parameter $\mathrm{P}_{\mathrm{A}}$ of Eqs. [1] and [2] has been introduced for a homogenized structure as $P_{\mathrm{A}}=\left[1 / T_{\mathrm{A}}-R / Q \cdot \ln \left(\mathrm{t}_{\mathrm{A}} /\right.\right.$ $60)]^{-1}$, where $T_{\mathrm{A}}(\mathrm{K})$ is the austenitization (holding) temperature, $t_{\mathrm{A}}(\mathrm{min})$ is the austenitization (holding) time, $R=1.987 \mathrm{cal} / \mathrm{mol} \mathrm{K}$, and $Q=110000 \mathrm{cal} / \mathrm{mol}^{[22]}$ The CCT measurements of Reference 12 in particular show that high $P_{\mathrm{A}}$ values, i.e., long holding at high temperatures, tend to delay the austenite decomposition process. This is explained by the homogenization of structure, dissolution of carbides, reduction of lattice defects and vacancies and grain growth. As IDS already takes into account the precipitate dissolution at high 
Table V. Experimental ${ }^{[13,20]}$ and Calculated (IDS) Temperatures of Primary Carbide Formation in High-Carbon Steels

\begin{tabular}{|c|c|c|c|c|c|c|}
\hline Steel & Composition (Weight Percent) & $R\left({ }^{\circ} \mathrm{C} / \mathrm{s}\right)$ & $T_{\mathrm{EXP}}\left({ }^{\circ} \mathrm{C}\right)$ & $T_{\mathrm{CAL}}\left({ }^{\circ} \mathrm{C}\right)$ & $\Delta T\left({ }^{\circ} \mathrm{C}\right)$ & Primary Carbide \\
\hline \multirow[t]{2}{*}{ CR01 } & $0.98 \mathrm{C} 0.29 \mathrm{Si} 0.39 \mathrm{Mn} 0.12 \mathrm{Cr} 0.215 \mathrm{Cu}$ & 0.020 & 727 & 729 & -2 & $(\mathrm{Fe}, \mathrm{Cr})_{3} \mathrm{C}$ \\
\hline & & 0.550 & 699 & 698 & 1 & $(\mathrm{Fe}, \mathrm{Cr})_{3} \mathrm{C}$ \\
\hline \multirow[t]{2}{*}{ CR02 } & $1 \mathrm{C} 0.22 \mathrm{Si} 1.12 \mathrm{Mn} 0.99 \mathrm{Cr} 0.12 \mathrm{Ni} 0.22 \mathrm{Cu}$ & 0.027 & 821 & 799 & 22 & $(\mathrm{Cr}, \mathrm{Fe})_{7} \mathrm{C}_{3}$ \\
\hline & & 4.575 & 747 & 731 & 16 & $(\mathrm{Cr}, \mathrm{Fe})_{7} \mathrm{C}_{3}$ \\
\hline \multirow[t]{3}{*}{ CR03 } & $0.97 \mathrm{C} 0.31 \mathrm{Si} 0.51 \mathrm{Mn} 1.5 \mathrm{Cr} 0.06 \mathrm{Mo} 1.55 \mathrm{Ni} 0.22 \mathrm{Cu}$ & 0.014 & 794 & 849 & -55 & $(\mathrm{Cr}, \mathrm{Fe})_{7} \mathrm{C}_{3}$ \\
\hline & & 0.146 & 784 & 810 & -26 & $(\mathrm{Cr}, \mathrm{Fe})_{7} \mathrm{C}_{3}$ \\
\hline & & 1.870 & 743 & 740 & 3 & $(\mathrm{Cr}, \mathrm{Fe})_{7} \mathrm{C}_{3}$ \\
\hline \multirow[t]{2}{*}{ CR04 } & $0.81 \mathrm{C} 0.26 \mathrm{Si} 0.46 \mathrm{Mn} 0.78 \mathrm{Cr} 0.04 \mathrm{Mo} 3.69 \mathrm{Ni} 0.16 \mathrm{Cu}$ & 0.005 & 712 & 690 & 22 & $(\mathrm{Cr}, \mathrm{Fe})_{7} \mathrm{C}_{3}$ \\
\hline & & 0.067 & 662 & 609 & 53 & $(\mathrm{Cr}, \mathrm{Fe})_{7} \mathrm{C}_{3}$ \\
\hline CR05 & $0.88 \mathrm{C} 0.3 \mathrm{Si} 0.66 \mathrm{Mn} 0.56 \mathrm{Cr} 0.44 \mathrm{Mo} 0.15 \mathrm{Ni} 0.18 \mathrm{Cu}$ & 0.006 & 770 & 772 & -2 & $\mathrm{Fe}_{3} \mathrm{Mo}_{3} \mathrm{C}$ \\
\hline \multirow[t]{3}{*}{ CR06 } & $1.11 \mathrm{C} 0.3 \mathrm{Si} 0.65 \mathrm{Mn} 0.12 \mathrm{Cr} 0.5 \mathrm{Mo}$ & 0.010 & 831 & 830 & 1 & $(\mathrm{Fe}, \mathrm{Mo})_{3} \mathrm{C}$ \\
\hline & & 0.129 & 801 & 823 & -22 & $(\mathrm{Fe}, \mathrm{Mo})_{3} \mathrm{C}$ \\
\hline & & 1.590 & 771 & 792 & -21 & $(\mathrm{Fe}, \mathrm{Mo})_{3} \mathrm{C}$ \\
\hline \multirow[t]{3}{*}{ TV01 } & $1 \mathrm{C} 0.28 \mathrm{Si} 0.52 \mathrm{Mn} 0.07 \mathrm{Cr} 0.03 \mathrm{Mo} 5 \mathrm{Ni}$ & 0.010 & 760 & 759 & 1 & $(\mathrm{Fe}, \mathrm{Mn})_{3} \mathrm{C}$ \\
\hline & & 0.100 & 727 & 735 & -8 & $(\mathrm{Fe}, \mathrm{Mn})_{3} \mathrm{C}$ \\
\hline & & 1.000 & 690 & 713 & -23 & $(\mathrm{Fe}, \mathrm{Mo})_{3} \mathrm{C}$ \\
\hline \multirow[t]{2}{*}{ TV02 } & $1 \mathrm{C} 1.88 \mathrm{Mn}$ & 0.010 & 745 & 753 & -8 & $(\mathrm{Fe}, \mathrm{Mn})_{3} \mathrm{C}$ \\
\hline & & 0.100 & 715 & 732 & -17 & $(\mathrm{Fe}, \mathrm{Mn})_{3} \mathrm{C}$ \\
\hline \multirow[t]{3}{*}{ TV03 } & $0.91 \mathrm{C} 0.23 \mathrm{Si} 0.65 \mathrm{Mn} 0.6 \mathrm{Cr} 1.35 \mathrm{Ni}$ & 0.010 & 735 & 720 & 15 & $(\mathrm{Cr}, \mathrm{Fe})_{7} \mathrm{C}_{3}$ \\
\hline & & 0.100 & 692 & 682 & 10 & $(\mathrm{Cr}, \mathrm{Fe})_{7} \mathrm{C}_{3}$ \\
\hline & & 1.000 & 634 & 645 & -11 & $(\mathrm{Cr}, \mathrm{Fe})_{7} \mathrm{C}_{3}$ \\
\hline \multirow[t]{3}{*}{ TV04 } & $0.95 \mathrm{C} 0.23 \mathrm{Si} 0.82 \mathrm{Mn} 0.52 \mathrm{Cr} 0.19 \mathrm{Mo} 0.56 \mathrm{Ni}$ & 0.010 & 761 & 727 & 34 & $(\mathrm{Cr}, \mathrm{Fe})_{7} \mathrm{C}_{3}$ \\
\hline & & 0.100 & 729 & 704 & 25 & $(\mathrm{Cr}, \mathrm{Fe})_{7} \mathrm{C}_{3}$ \\
\hline & & 1.000 & 682 & 679 & 3 & $(\mathrm{Cr}, \mathrm{Fe})_{7} \mathrm{C}_{3}$ \\
\hline \multirow[t]{3}{*}{ TV05 } & $0.97 \mathrm{C} 0.52 \mathrm{Mn} 0.19 \mathrm{Mo} 3.36 \mathrm{Ni}$ & 0.010 & 745 & 720 & 25 & $(\mathrm{Fe}, \mathrm{Mn})_{3} \mathrm{C}$ \\
\hline & & 0.100 & 712 & 698 & 14 & $(\mathrm{Fe}, \mathrm{Mn})_{3} \mathrm{C}$ \\
\hline & & 1.000 & 668 & 684 & -16 & $(\mathrm{Fe}, \mathrm{Mn})_{3} \mathrm{C}$ \\
\hline \multirow[t]{3}{*}{ TV06 } & $0.97 \mathrm{C} 1.04 \mathrm{Mn} 0.32 \mathrm{Mo}$ & 0.010 & 736 & 715 & 21 & $(\mathrm{Fe}, \mathrm{Mn})_{3} \mathrm{C}$ \\
\hline & & 0.100 & 706 & 696 & 10 & $(\mathrm{Fe}, \mathrm{Mn})_{3} \mathrm{C}$ \\
\hline & & 1.000 & 666 & 683 & -17 & $(\mathrm{Fe}, \mathrm{Mn})_{3} \mathrm{C}$ \\
\hline \multirow[t]{3}{*}{ TV07 } & $1.13 \mathrm{C} 0.3 \mathrm{Mn}$ & 0.010 & 839 & 850 & -11 & $(\mathrm{Fe}, \mathrm{Mn})_{3} \mathrm{C}$ \\
\hline & & 0.100 & 828 & 844 & -16 & $(\mathrm{Fe}, \mathrm{Mn})_{3} \mathrm{C}$ \\
\hline & & 1.000 & 813 & 827 & -14 & $(\mathrm{Fe}, \mathrm{Mn})_{3} \mathrm{C}$ \\
\hline
\end{tabular}

CR steels are from Ref. [13] and TV steels are from Ref. [20]. The applied IDS temperature history is $R_{\mathrm{COOL}}=1{ }^{\circ} \mathrm{C} / \mathrm{s}, T_{\mathrm{MIN}}=750{ }^{\circ} \mathrm{C}, R_{\mathrm{HEAT}}=$ $10{ }^{\circ} \mathrm{C} / \mathrm{s}, T_{\mathrm{HOLD}}=930^{\circ} \mathrm{C}(\mathrm{CR}$ steels $)$, and $t_{\mathrm{HOLD}}=30 \mathrm{~min}(\mathrm{CR}$ steels $)$. For the TV steels, $\mathrm{T}_{\mathrm{HOLD}}$ varied between 920 and $800{ }^{\circ} \mathrm{C}$, and $\mathrm{t}_{\mathrm{HOLD}}$ varied between 15 and $30 \mathrm{~min}$.

temperatures, we assume that $P_{\mathrm{A}}$ just describes the preferable nucleation sites for the onset of the austenite decomposition process. Thus, a high $P_{\mathrm{A}}$ value means fewer nucleation sites and a delay in the decomposition of austenite. When applying the IDS to calculate the soluble compositions for optimization, we use a cooling rate of $1{ }^{\circ} \mathrm{C} / \mathrm{s}$ and a heating rate of $10^{\circ} \mathrm{C} / \mathrm{s}$, taking into account the reported holding for each CCT steel. ${ }^{[1-13]}$

In Eqs. [1] and [2], terms $a_{i}(i \neq 1)$ represent the first-order solute effects, terms $b_{i j}$ represent the second-order solute effects, terms $c_{1}$ and $c_{2}$ represent the effect of cooling rate $R$, and term $c_{3}$ represents the effect of austenitization parameter $P_{\mathrm{A}}$. Six equations for $T^{\phi}$ of Eq. [1] and seven equations for $R^{\phi}$ of Eq. [2] were optimized for the calculation of the following information.

- $T^{\mathrm{F}}$ temperature for the start of proeutectoid ferrite formation $\left(=\mathrm{Ar}_{3}\right)$

- $T^{\mathrm{P}}$ temperature for the start of pearlite formation

- $T^{\mathrm{P}}-T^{\mathrm{P}}$ temperature range of pearlite formation $\left(T^{\mathrm{P}}\right.$ $=$ end of pearlite formation)
- $T^{\mathrm{B}}$ temperature for the start of bainite formation

- $T^{\mathrm{BE} 0}$ temperature for the end of bainite formation from a structure of $\approx 0$ pct austenite

- $T^{\mathrm{M} 100}$ temperature for the start of martensite from a structure of 100 pct austenite

- $R^{\mathrm{F}}$ maximal cooling rate of proeutectoid ferrite formation

- $R^{\mathrm{P}}$ maximal cooling rate of pearlite formation

- $R^{\mathrm{BM0}}$ maximal cooling rate leading to no formation of bainite and martensite

- $R^{\mathrm{M} 0}$ maximal cooling rate leading to formation of bainite with no martensite

- $R^{\mathrm{M} 20}$ cooling rate leading to bainite and martensite formation with 20 pct martensite

- $R^{\mathrm{M} 80}$ cooling rate leading to bainite and martensite formation with 80 pct martensite

- $R^{\mathrm{M} 100}$ minimal cooling rate leading to formation of 100 pct martensite

Using these equations, a CCT diagram of the type shown in Figure 3, can be constructed. It is to be noted that it was safer to optimize the temperature range of pearlite formation, $T^{\mathrm{P}}-T^{\mathrm{P}}$, than the pearlite end 


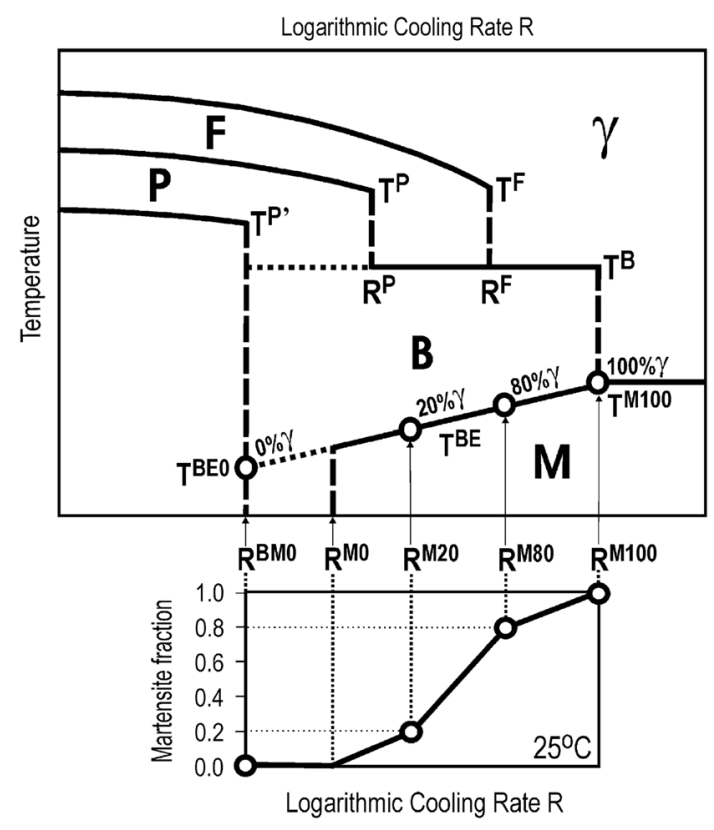

Fig. 3-Phase transformation structures formed from austenite $(\gamma)$ during cooling ( $F$ proeutectoid ferrite, $P$ pearlite, $B$ bainite, $M$ martensite) and the final martensite fractions at $25^{\circ} \mathrm{C}$. Temperature $T^{\mathrm{BE}}$ is a hypothetical bainite end temperature used in the calculations of IDS.

temperature, $T^{\mathrm{P}^{\prime}}$, because the value of $T^{\mathrm{P}^{\prime}}$ could sometimes become higher than that of $T^{\mathrm{P}}$. Also noteworthy is the fact that Eqs. [1] and [2] usually simplify the shapes of the transformation regions. The real transformation 'noses' are usually more curved and the temperature $T^{\mathrm{B}}$ of bainite formation is not constant. Moreover, the experimental CCT-temperature values always correspond to some detected small fraction of the new phase, whereas the temperatures calculated by Eq. [1] refer to zero-value phase fractions. This of course causes a slight discrepancy in the results. Equations [1] and [2] were also applied in the earlier study of Reference 6, but directly considering the nominal steel compositions instead of the IDS-calculated soluble composition. However, the new equation for $R^{\mathrm{M} 0}$ was not considered previously. ${ }^{[6]}$ In calculations, it allows to get a final structure containing bainite without any martensite, which is more likely in certain steels than expected by Reference 6.

The optimized values for parameters $a_{i}, b_{i j}$, and $c_{k}$ of Eqs. [1] and [2] are given in Tables VI and VII. These parameters were manually added or discarded from the optimization to improve the correlation. In spite of this exercise, some of the parameters may not be essential in the calculations. They can give realistic results only inside the composition ranges of the steels (included in the optimization), beyond which the results may become uncertain, depending on their crossing. As a rough estimate, upper limits for the compositions applied in Eqs. [1] and [2] with the present parameter values are given as 3 wt pct $\mathrm{C}, 2$ wt pct $\mathrm{Si}, 3$ wt pct $\mathrm{Mn}, 3$ wt pct $\mathrm{Cr}, 0.5 \mathrm{wt}$ pct Mo, and 3 wt pct Ni. Note, however, that these are nominal compositions for the steels, whereas Eqs. [1] and [2] apply the soluble compositions calculated by the IDS. Tables VI and VII also show the number of experimental data points used, the average error between the calculations, the original CCT data, and the correlation coefficient. As can be seen, the average error for each start temperature of Table VI is between 15 and $21{ }^{\circ} \mathrm{C}$. The agreement is reasonable, but not yet excellent. Several trials based on different parameter combinations were made to improve the correlation, but only slight improvement was obtained, even by introducing very complex and unusual parameter combinations. This was essentially due to the inconsistencies in the original experimental data. In fact, even before the optimization, some selection was made in the experimental CCT diagrams. Any piece of information, which deviated markedly from the predicted behavior, was rejected from the analysis, as it decreased the correlation coefficient of the analysis. Typically, rejections were made for critical cooling rates of ferrite and pearlite formation, when their criticality could not be ascertained clearly from the CCT diagrams. Sometimes, even the whole diagram was rejected if it showed an exceptionally weak tendency for austenite to decompose in the experimental cooling rate range, as was the case in some alloyed steels containing $\mathrm{Cr}$, Mo, and $\mathrm{Ni}$.

As an example of the optimization, Figure 4 illustrates the correlation obtained between the experimental and the calculated start temperatures of proeutectoid ferrite formation. On the whole, the resulting correlation coefficients for the equations are no better than those of the earlier analysis. ${ }^{[6]}$ This is due to the general scatter in the CCT measurements by research groups in Germany ${ }^{[12,13]}$ and by the British Steel Corporation. ${ }^{[14]}$ The scatter can be caused due to variations in local composition, grain size, cooling rate, and even micro- and macro-segregation-related issues inherited from original castings and requires several repeated tests to ascertain phase transformation behavior, measure the CCT temperatures for particular cooling rates, and determine the average CCT curves. Some uncertainty in the final results may also result from the logarithmic scaling of time or cooling rate used in the original CCT diagrams. The parameters of Eqs. [1] and [2], however, are clearly different from the earlier ones, due to the use of the IDS-calculated grain boundary soluble compositions. As these parameters do not give any impression of how far the soluble compositions can deviate from the nominal ones, an example simulation illustrating that was conducted.

\section{VALIDATION OF CALCULATIONS WITH MEASUREMENTS}

The CCT data measured for steel A (Table I) recently were compared with the CCT data calculated using the IDS in respect of both the start temperatures and the final phase fractions of the austenite decomposition process, considering the observed average grain size of $130 \mu \mathrm{m}$ in the calculations. The transformation kinetics predictions of the IDS ADC module were included ${ }^{[6]}$ in the calculations of the final phase fractions. The results 
Table VI. Parameters $a_{i}, b_{i j}, c_{1}, c_{2}$, and $c_{3}$ of Eq. [1] for the Calculation of Phase Formation Temperatures $T^{\phi}\left({ }^{\circ} \mathrm{C}\right)$

\begin{tabular}{|c|c|c|c|c|c|c|}
\hline Parameter & $T^{\mathrm{F}}$ & $T^{\mathrm{P}}$ & $T^{\mathrm{P}}-T^{\mathrm{P}^{\prime}}$ & $T^{\mathrm{B}}$ & $T^{\mathrm{BE} 0}$ & $T^{\mathrm{M} 100}$ \\
\hline $\mathrm{a} 0$ & 945.03 & 804.75 & 65.17 & 589.64 & 482.41 & 561.40 \\
\hline $\mathrm{C}$ & -465.51 & -71.93 & -24.02 & -156.63 & -437.80 & -611.00 \\
\hline $\mathrm{Si}$ & -26.92 & -79.54 & -27.96 & -58.59 & -1.12 & 61.38 \\
\hline $\mathrm{Mn}$ & -33.82 & -29.76 & 27.05 & 69.41 & -42.45 & -41.65 \\
\hline $\mathrm{Cr}$ & -53.91 & -17.90 & -5.24 & -1.78 & -37.47 & -24.87 \\
\hline Mo & -22.06 & -29.33 & 43.65 & 172.24 & -155.45 & -37.07 \\
\hline $\mathrm{Ni}$ & -27.93 & -1.35 & 24.08 & 13.00 & -73.80 & -8.67 \\
\hline $\mathrm{CC}$ & 309.95 & 45.24 & -4.40 & 109.94 & 160.24 & 237.04 \\
\hline $\mathrm{CSi}$ & -18.67 & 19.81 & 59.02 & -8.70 & -33.41 & -45.82 \\
\hline CMn & -14.51 & 1.99 & 2.04 & -18.99 & 23.98 & 27.04 \\
\hline $\mathrm{CCr}$ & 77.77 & 35.07 & 0.95 & -17.67 & 32.02 & 16.67 \\
\hline CMo & -142.85 & -6.91 & -13.41 & -33.52 & 94.47 & -21.05 \\
\hline $\mathrm{CNi}$ & 19.95 & -11.45 & 7.50 & -20.39 & 24.94 & 0.43 \\
\hline $\mathrm{SiSi}$ & 16.40 & 28.26 & 7.90 & 21.75 & -6.16 & -6.93 \\
\hline SiMn & 15.01 & 10.94 & -22.33 & 4.85 & 33.05 & -19.74 \\
\hline $\mathrm{SiCr}$ & 26.95 & 24.24 & 5.52 & 16.73 & 14.94 & 8.73 \\
\hline SiMo & 57.84 & 14.55 & -5.70 & -29.40 & 20.83 & 1.91 \\
\hline $\mathrm{SiNi}$ & 8.04 & 2.16 & -40.47 & 4.21 & 21.33 & -10.53 \\
\hline MnMn & -4.13 & -5.05 & -6.13 & -28.03 & -7.26 & 6.02 \\
\hline $\mathrm{MnCr}$ & 2.57 & -7.66 & -3.72 & -18.46 & -13.57 & 0.86 \\
\hline MnMo & -14.13 & -28.25 & 32.39 & -88.51 & -11.92 & 15.02 \\
\hline $\mathrm{MnNi}$ & -0.56 & -17.82 & -10.55 & -13.35 & 6.30 & -0.56 \\
\hline $\mathrm{CrCr}$ & 1.37 & 1.31 & 2.23 & 1.04 & 2.52 & 1.37 \\
\hline CrMo & 25.70 & 6.51 & -16.83 & -53.83 & 6.69 & 15.86 \\
\hline $\mathrm{CrNi}$ & 2.09 & -2.70 & -1.87 & -8.97 & 3.21 & 0.10 \\
\hline MoMo & 74.47 & 32.92 & -17.59 & -45.11 & 62.02 & 30.80 \\
\hline MoNi & -21.70 & -23.39 & -18.16 & -29.03 & 7.97 & -2.99 \\
\hline $\mathrm{NiNi}$ & -2.70 & -3.79 & -1.78 & -1.92 & 7.54 & -0.88 \\
\hline $\mathrm{cl}$ & -0.399 & -0.319 & 0.818 & 0 & 0 & 0 \\
\hline $\mathrm{c} 2$ & -8.590 & -8.771 & 2.677 & 0 & 0 & 0 \\
\hline c3 & -0.05256 & -0.06163 & -0.02069 & 0 & 0 & 0 \\
\hline Data points & 611 & 709 & 355 & 200 & 173 & 221 \\
\hline Average Error & 16.17 & 19.01 & 9.51 & 18.97 & 20.28 & 15.85 \\
\hline Corr. Coef. & 0.957 & 0.901 & 0.813 & 0.925 & 0.963 & 0.986 \\
\hline
\end{tabular}

are presented in Table VIII showing fairly good agreement. The only inconsistency is seen in the cooling rate of $20^{\circ} \mathrm{C} / \mathrm{s}$, as pearlite formed according to the measurements, whereas the predictions suggested formation of martensite without any pearlite. Also, the metallography revealed different types of ferrites, like proeutectoid, Widmanstätten, aligned side plates, and acicular ferrite. It should be pointed out that the calculations do not differentiate between different types of ferrite.

When applying the CCT equations from the earlier study, ${ }^{[6]}$ the predictions are relatively less accurate. This is illustrated in Table IX which presents a comparison of the measured austenite decomposition temperatures calculated in the present study with those predicted using the previous equations published earlier. ${ }^{[6]}$ As can be seen, the old equations predict suppression of ferrite and pearlite formation at high cooling rates, thus enabling just martensite formation. Consequently, the final phase fractions (not shown here) also deviate considerably from the measured values. It should, however, be noted that the present predictions are better not only due to the new CCT equations based on grain boundary composition, but also due to the recent improvements in the IDS theory and input data. Thus, the purpose of the present calculations made for steel A is to showcase the general progress made in the development of IDS software to simulate and predict the austenite decomposition process. However, due to the low manganese segregation of the alloy (see Table III), Steel A is not the best example for comparing the results obtained by soluble and nominal solute compositions. For making a general comparison encompassing a broad range of alloying additions, additional calculations were made as shown in the next section.

\section{VALIDATION OF CALCULATIONS WITH MEASUREMENTS USING SOLUBLE AND NOMINAL COMPOSITION-BASED CCT EQUATIONS}

As the austenite decomposition process is believed to start with the grain boundary soluble compositions rather than the nominal ones, it is interesting to see how the calculations made by Eqs. [1] and [2], after using 
Table VII. Parameters $a_{i}, b_{i j}$, and $c_{1}$ of Eq. [2] for the Calculation of Critical Cooling Rates $R^{\phi}\left({ }^{\circ} \mathrm{C} / \mathrm{s}\right)$

\begin{tabular}{|c|c|c|c|c|c|c|c|}
\hline Parameter & $R^{\mathrm{F}}$ & $R^{\mathrm{P}}$ & $R^{\mathrm{BM} 0}$ & $R^{\mathrm{M} 0}$ & $R^{\mathrm{M} 20}$ & $R^{\mathrm{M} 80}$ & $R^{\mathrm{M} 100}$ \\
\hline $\mathrm{a} 0$ & 6.253 & 6.031 & 4.168 & 6.775 & 6.186 & 6.075 & 5.837 \\
\hline $\mathrm{C}$ & -5.471 & -1.843 & -0.653 & -2.177 & -3.428 & -4.588 & -3.353 \\
\hline $\mathrm{Si}$ & -0.149 & -0.857 & -0.581 & -2.032 & -0.131 & 0.769 & 0.144 \\
\hline $\mathrm{Mn}$ & -0.380 & -1.310 & -1.325 & -0.457 & -0.216 & -0.146 & -0.516 \\
\hline $\mathrm{Cr}$ & -1.222 & -1.398 & -1.092 & -0.917 & -0.405 & -0.219 & -0.501 \\
\hline Mo & -2.647 & -4.430 & -5.341 & -4.531 & -1.902 & -0.605 & -0.178 \\
\hline $\mathrm{Ni}$ & -0.271 & -0.689 & -1.302 & -0.926 & -0.136 & -0.162 & 0.003 \\
\hline $\mathrm{CC}$ & 4.122 & 0.949 & 0.568 & 0.961 & 2.002 & 2.832 & 1.852 \\
\hline $\mathrm{CSi}$ & -0.717 & 0.562 & -0.740 & 1.524 & -0.625 & -1.212 & -0.866 \\
\hline CMn & 0.059 & -0.148 & -0.085 & -0.434 & 0.417 & 0.416 & -0.347 \\
\hline $\mathrm{CCr}$ & -0.664 & 1.015 & 0.781 & 0.938 & 0.140 & -0.167 & -0.060 \\
\hline CMo & 0.082 & 1.517 & 0.439 & 0.916 & -0.181 & -0.302 & 0.100 \\
\hline $\mathrm{CNi}$ & -0.582 & -0.067 & -0.045 & -0.448 & -0.610 & -0.512 & -0.443 \\
\hline $\mathrm{SiSi}$ & 0.040 & 0.026 & 0.196 & 0.350 & 0.281 & 0.058 & 0.099 \\
\hline SiMn & 0.306 & 0.453 & 0.485 & -0.034 & -0.456 & -0.380 & -0.035 \\
\hline $\mathrm{SiCr}$ & 0.819 & -0.104 & 0.170 & 0.384 & 0.212 & -0.018 & -0.006 \\
\hline SiMo & 1.212 & 1.052 & 0.907 & 0.429 & 0.261 & 0.353 & 0.065 \\
\hline $\mathrm{SiNi}$ & 0.042 & -0.775 & 0.037 & -0.115 & -0.608 & -0.246 & 0.301 \\
\hline MnMn & -0.179 & 0.186 & 0.120 & 0.001 & -0.126 & -0.139 & 0.064 \\
\hline $\mathrm{MnCr}$ & 0.237 & 0.097 & 0.157 & -0.555 & -0.653 & -0.423 & 0.092 \\
\hline MnMo & -0.412 & -0.270 & 0.233 & 1.849 & 0.621 & -0.028 & -0.256 \\
\hline $\mathrm{MnNi}$ & -0.069 & 0.306 & 0.465 & 0.542 & 0.431 & 0.175 & -0.164 \\
\hline $\mathrm{CrCr}$ & 0.079 & 0.094 & -0.033 & 0.095 & 0.052 & 0.053 & -0.022 \\
\hline CrMo & 0.491 & 0.717 & 0.679 & 0.432 & 0.335 & -0.001 & -0.035 \\
\hline $\mathrm{CrNi}$ & -0.025 & 0.183 & 0.227 & -0.098 & -0.066 & -0.089 & -0.065 \\
\hline MoMo & 0.355 & 0.809 & 2.073 & 0.665 & 0.628 & 0.039 & -0.093 \\
\hline $\mathrm{MoNi}$ & -0.110 & -0.339 & 0.086 & 0.094 & -0.028 & -0.058 & -0.265 \\
\hline $\mathrm{NiNi}$ & -0.013 & 0.003 & 0.054 & 0.112 & -0.020 & -0.014 & -0.049 \\
\hline c3 & -0.00200 & -0.00227 & -0.00158 & -0.00322 & -0.00269 & -0.00224 & -0.00168 \\
\hline Data Points & 199 & 255 & 228 & 242 & 250 & 238 & 271 \\
\hline Average Error & 0.287 & 0.368 & 0.329 & 0.312 & 0.348 & 0.291 & 0.286 \\
\hline Corr. Coeff. & 0.971 & 0.959 & 0.966 & 0.965 & 0.932 & 0.953 & 0.953 \\
\hline
\end{tabular}

The given average errors and correlation coefficients are based on the usage of expressions $\log (\mathrm{R})$.

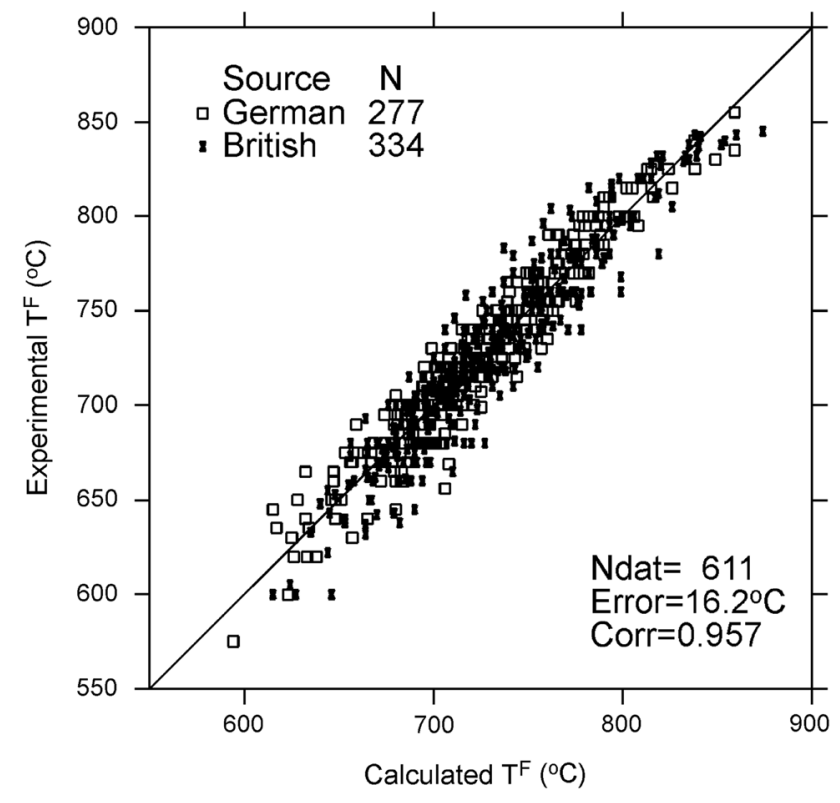

Fig. 4 -A comparison of the experimental ${ }^{[12-14]}$ and the calculated start temperatures for proeutectoid ferrite formation. both composition types in their optimization, correlate with the measurements. For that purpose, five high-carbon steels of Reference 13 shown in Table X were selected. As they all contain enough chromium and manganese to form lots of carbides, the soluble compositions will be very different from the nominal ones, making this comparison quite illustrative. For that matter, even alloys with much higher carbon contents (CR3: 2.6 and CR5: $3.2 \mathrm{wt}$ pct) beyond the theoretical limit of $2.1 \mathrm{wt}$ pct for steels were also included in this study to examine the robustness of the new equations. The results of these calculations are presented in Table XI. The agreement between the measured ${ }^{[13]}$ and the calculated austenite decomposition temperatures is much better when applying the grain boundary soluble compositions in the optimization instead of the nominal ones. The temperature differences between the experimental and predicted data are given in brackets which clearly show the merits of the new equations. In addition, using the nominal compositions does not show any formation of bainite, whereas both the experimental measurements and the soluble composition-based calculations indicate its formation. 
Table VIII. Experimental and Calculated (IDS) Austenite Decomposition Start Temperatures and the Final Phase Fractions (Volume Percent) at $25^{\circ} \mathrm{C}$ for steel A (Table I)

\begin{tabular}{|c|c|c|c|c|c|c|c|c|c|c|c|c|c|c|c|c|c|}
\hline \multirow[b]{2}{*}{ No } & \multirow[b]{2}{*}{$R\left({ }^{\circ} \mathrm{C} / \mathrm{s}\right)$} & \multicolumn{2}{|c|}{$T^{\mathrm{F}}\left({ }^{\circ} \mathrm{C}\right)$} & \multicolumn{2}{|c|}{$T^{\mathrm{P}}\left({ }^{\circ} \mathrm{C}\right)$} & \multicolumn{2}{|c|}{$T^{\mathrm{B}}\left({ }^{\circ} \mathrm{C}\right)$} & \multicolumn{2}{|c|}{$T^{\mathrm{M}}\left({ }^{\circ} \mathrm{C}\right)$} & \multicolumn{2}{|c|}{$\mathrm{F}(\mathrm{Pct})$} & \multicolumn{2}{|c|}{$\mathrm{P}(\mathrm{Pct})$} & \multicolumn{2}{|c|}{$\mathrm{B}(\mathrm{Pct})$} & \multicolumn{2}{|c|}{ M (Pct) } \\
\hline & & Exp & $\mathrm{Cal}$ & Exp & $\mathrm{Cal}$ & Exp & $\mathrm{Cal}$ & Exp & $\mathrm{Cal}$ & Exp & Cal & Exp & $\mathrm{Cal}$ & Exp & $\mathrm{Cal}$ & Exp & $\mathrm{Ca}$ \\
\hline 1 & 1 & 765 & 756 & 670 & 663 & - & - & - & - & 70 & 69 & 30 & 31 & - & - & - & - \\
\hline 2 & 2 & 745 & 748 & 660 & 655 & - & - & - & - & 65 & 62 & 35 & 38 & - & - & - & - \\
\hline 3 & 5 & 740 & 738 & 650 & 646 & 620 & 605 & - & - & 55 & 50 & 15 & 14 & 30 & 34 & - & - \\
\hline 4 & 7.5 & 730 & 734 & 640 & 641 & 620 & 605 & - & - & 43 & 45 & 10 & 13 & 47 & 42 & - & - \\
\hline 5 & 10 & 727 & 730 & 630 & 638 & 620 & 605 & - & - & 39 & 41 & 6 & 12 & 55 & 47 & - & - \\
\hline 6 & 20 & 718 & 720 & 625 & - & 620 & 605 & - & 399 & 33 & 23 & 2 & - & 65 & 62 & - & 15 \\
\hline 7 & 30 & 715 & 713 & - & - & 610 & 605 & 410 & 406 & 15 & 15 & - & - & 55 & 52 & 30 & 32 \\
\hline 8 & 50 & 692 & 700 & - & - & 600 & 605 & 410 & 415 & 10 & 9 & - & - & 30 & 31 & 60 & 59 \\
\hline
\end{tabular}

F: proeutectoid ferrite, P: pearlite, B: bainite, M: martensite.

Table IX. A Comparison of Experimental Austenite Decomposition Start Temperatures of Steel A (Table I) with the Values Calculated by IDS Using Eqs. [1] and [2] of this Study (Cal-New) and Those of the Earlier Study ${ }^{[6]}$ (Cal-Old)

\begin{tabular}{|c|c|c|c|c|c|c|c|c|c|c|c|c|c|}
\hline \multirow[b]{2}{*}{ No } & \multirow[b]{2}{*}{$R\left({ }^{\circ} \mathrm{C} / \mathrm{s}\right)$} & \multicolumn{3}{|c|}{$T^{\mathrm{F}}\left({ }^{\circ} \mathrm{C}\right)$} & \multicolumn{3}{|c|}{$T^{\mathrm{P}}\left({ }^{\circ} \mathrm{C}\right)$} & \multicolumn{3}{|c|}{$T^{\mathrm{B}}\left({ }^{\circ} \mathrm{C}\right)$} & \multicolumn{3}{|c|}{$T^{\mathrm{M}}\left({ }^{\circ} \mathrm{C}\right)$} \\
\hline & & Exp & Cal-New & Cal-Old & Exp & Cal-New & Cal-Old & Exp & Cal-New & Cal-Old & Exp & Cal-New & Cal-Old \\
\hline 1 & 1 & 765 & 756 & 729 & 670 & 663 & 628 & - & - & 602 & - & - & 357 \\
\hline 2 & 2 & 745 & 748 & 722 & 660 & 655 & - & - & - & 603 & - & - & 369 \\
\hline 3 & 5 & 740 & 738 & 712 & 650 & 646 & - & 620 & 605 & 603 & - & - & 384 \\
\hline 4 & 7.5 & 730 & 734 & 707 & 640 & 641 & - & 620 & 605 & 603 & - & - & 391 \\
\hline 5 & 10 & 727 & 730 & 703 & 630 & 638 & - & 620 & 605 & 603 & - & - & 396 \\
\hline 6 & 20 & 718 & 720 & - & 625 & - & - & 620 & 605 & 603 & - & 399 & 398 \\
\hline 7 & 30 & 715 & 713 & - & - & - & - & 610 & 605 & 603 & 410 & 406 & 414 \\
\hline 8 & 50 & 692 & 700 & - & - & - & - & 600 & 605 & 603 & 410 & 415 & 423 \\
\hline
\end{tabular}

F: proeutectoid ferrite, P: pearlite, B: bainite, M: martensite.

Table X. Nominal Composition of Five High-Carbon Steels ${ }^{[13]}$ Used to Test the Effects of Soluble and Nominal Compositions on the Calculated Austenite Decomposition Products

\begin{tabular}{lcccccccc}
\hline Steel & $\begin{array}{c}\text { C (Weight } \\
\text { Percent) }\end{array}$ & $\begin{array}{c}\text { Si (Weight } \\
\text { Percent) }\end{array}$ & $\begin{array}{c}\text { Mn (Weight } \\
\text { Percent) }\end{array}$ & $\begin{array}{c}\text { Cr (Weight } \\
\text { Percent) }\end{array}$ & $\begin{array}{c}\text { Mo (Weight } \\
\text { Percent) }\end{array}$ & $\begin{array}{c}\text { Ni (Weight } \\
\text { Percent) }\end{array}$ & $\begin{array}{c}\text { Cu (Weight } \\
\text { Percent) }\end{array}$ & $\begin{array}{c}\text { S (Weight } \\
\text { Percent) }\end{array}$ \\
\hline CR1 & 1.00 & 0.22 & 1.12 & 0.99 & 0.02 & 0.12 & 0.22 \\
CR2 & 0.97 & 0.31 & 0.51 & 1.50 & 0.06 & 1.55 & 0.22 \\
CR3 & 2.60 & 0.31 & 0.51 & 1.50 & 0.06 & 1.55 & 0.22 \\
CR4 & 1.10 & 0.31 & 0.50 & 1.95 & 0.03 & 2.02 & 0.009 \\
CR5 & 3.20 & 0.31 & 0.50 & 1.95 & 0.03 & 2.02 & 0.009 \\
\hline
\end{tabular}

Due to the clear differences in these results, one can inquire as to their origin. The predictions for the nominal compositions were only slightly inferior compared to those predicted using the soluble compositions. One explanation is that the former types of equation are inflexible and fail to take into account the high nominal compositions of carbon and chromium, such as those present in steels CR3 and CR5. Their calculated soluble compositions are instead much lower, which make the equations more flexible to handle different sets of solute compositions. This, of course, explains the different results only mathematically. In reality, it is reasonable to think that the austenite decomposition process, starting from the grain boundaries, cannot correspond well with the average composition of the steel. In that sense, the nominal composition-based CCT equations may even be misleading, in spite of the reasonable correlation obtained in their optimization.

\section{SUMMARY AND CONCLUDING REMARKS}

In the present work, thirteen CCT equations were optimized using the CCT diagrams made in Germany ${ }^{[12,13]}$ and Britain ${ }^{[14]}$ to simulate the phase transformation start temperatures of the austenite decomposition process in low-alloyed steels. These equations are applied in the IDS software to simulate 
Table XI. A Comparison of Experimental Austenite Decomposition Temperatures of Five High-Carbon Steels (Table X) Calculated Using the IDS and the Eqs. [1] and [2] Optimized by Soluble Compositions (Cal-Sol) and the Nominal Compositions (Cal-Nom)

\begin{tabular}{|c|c|c|c|c|c|c|c|c|c|c|}
\hline \multirow[b]{2}{*}{ No } & \multirow[b]{2}{*}{$R\left({ }^{\circ} \mathrm{C} / \mathrm{s}\right)$} & \multicolumn{3}{|c|}{$T^{\mathrm{P}}\left({ }^{\circ} \mathrm{C}\right)$} & \multicolumn{3}{|c|}{$T^{\mathrm{B}}\left({ }^{\circ} \mathrm{C}\right)$} & \multicolumn{3}{|c|}{$T^{\mathrm{M}}\left({ }^{\circ} \mathrm{C}\right)$} \\
\hline & & Exp & Cal-Sol & Cal-Nom & Exp & Cal-Sol & Cal-Nom & Exp & Cal-Sol & Cal-Nom \\
\hline \multirow[t]{4}{*}{ CR1 } & 0.004 & 710 & 709 (1) & $698(12)$ & - & - & - & - & - & - \\
\hline & 0.300 & 690 & $682(8)$ & $662(28)$ & - & - & - & - & - & - \\
\hline & 7.600 & 640 & $629(11)$ & no pea & 535 & $538(-3)$ & $468(67)$ & 175 & $176(-1)$ & $140(35)$ \\
\hline & 15.500 & - & - & - & 530 & $539(-9)$ & no $\mathrm{B}$ & 175 & $183(-8)$ & $140(35)$ \\
\hline \multirow[t]{4}{*}{ CR2 } & 0.004 & 690 & $688(2)$ & $681(9)$ & - & - & - & - & - & - \\
\hline & 0.077 & 675 & $663(12)$ & 657 (18) & - & - & - & - & - & - \\
\hline & 0.900 & 645 & $645(0)$ & no pea & 500 & $512(-12)$ & $470(30)$ & 175 & $172(3)$ & $152(23)$ \\
\hline & 4.000 & - & - & - & 510 & $518(-8)$ & no B & 160 & $170(-10)$ & $155(5)$ \\
\hline \multirow[t]{3}{*}{ CR3 } & 0.004 & 680 & $687(-7)$ & $678(2)$ & - & - & - & - & - & - \\
\hline & 0.190 & 640 & 639 (1) & $646(-6)$ & - & - & - & - & - & - \\
\hline & 1.840 & 600 & $611(-11)$ & $625(-25)$ & 540 & $549(-9)$ & $522(18)$ & 170 & $150(20)$ & $116(54)$ \\
\hline \multirow[t]{4}{*}{ CR4 } & 0.004 & 680 & $676(4)$ & $660(20)$ & - & - & - & - & - & - \\
\hline & 0.044 & 665 & $654(11)$ & $641(24)$ & - & - & - & - & - & - \\
\hline & 0.300 & 640 & $634(6)$ & $624(16)$ & 515 & $505(10)$ & $426(89)$ & 170 & $142(28)$ & $108(62)$ \\
\hline & 2.300 & - & - & - & 500 & $508(-8)$ & no $\mathrm{B}$ & 155 & $163(-8)$ & $108(47)$ \\
\hline \multirow[t]{4}{*}{ CR5 } & 0.004 & 655 & $649(6)$ & $657(-2)$ & - & - & - & - & - & - \\
\hline & 0.034 & 627 & $617(10)$ & $640(-13)$ & - & - & - & - & - & - \\
\hline & 0.300 & 600 & $593(7)$ & $621(-21)$ & 515 & $519(-4)$ & $537(-22)$ & 160 & 147 (13) & no $M$ \\
\hline & 2.500 & - & - & $601(601)$ & 500 & $509(-9)$ & $537(-37)$ & 160 & $140(20)$ & $230(-70)$ \\
\hline
\end{tabular}

Numbers in brackets denote the differences between the experimental and calculated temperatures. The temperature history used in IDS is $R_{\mathrm{COOL}}$ $=1{ }^{\circ} \mathrm{C} / \mathrm{s}, T_{\mathrm{MIN}}=700{ }^{\circ} \mathrm{C}, R_{\mathrm{HEAT}}=10^{\circ} \mathrm{C} / \mathrm{s}, T_{\mathrm{HOLD}}=830^{\circ} \mathrm{C}, t_{\mathrm{HOLD}}=15 \mathrm{~min}$. P: pearlite, B: bainite, M: martensite.

the austenite decomposition process also taking the kinetics into account. The new method proposed in this study is based on the use of the IDS-calculated soluble compositions of the austenite grain boundaries, vis-à-vis the earlier treatment of Reference 6 applied nominal compositions of the selected steels in the optimization. Due to the microsegregation of solutes and their tendency to form certain precipitates in some cases, the soluble compositions may be quite far from the nominal ones, thus rendering the use of the nominal composition-based CCT equations questionable, at least when the austenite decomposition initiates at the grain boundaries. To show how different these compositions can be in highly alloyed steels, a demonstrative calculation was carried out. In addition, the earlier optimized CCT equation for the prediction of the start temperature of proeutectoid carbide formation ${ }^{[6]}$ was replaced with the IDS-calculated carbide formation temperatures since the experimental CCT data did not give precise start temperature values for their formation.

The calculations made by the IDS software using the new CCT equations were compared with the new experimental measurements in this study made for a low-alloyed steel. The agreement was good both in respect of the austenite decomposition temperatures as well as the final phase fractions. In the latter case, the results were also affected by the low-temperature phase transformation kinetics of the software. In addition, the new soluble composition-based equations were tested by comparing the calculations with those of the nominal composition-based equations, with respect to the austenite decomposition temperatures measured for high-carbon steels. A much better agreement was obtained with the former equations, indicating that one should always apply soluble compositions while simulating the austenite decomposition process starting from the grain boundary area.

In the new method, we have two specific problems. The first one is related to the temperature histories of the steels used in the CCT optimization. Truly speaking, we hardly know these histories completely, except for their reported holding treatments and cooling rates prior to the austenite decomposition process. Consequently, the soluble compositions calculated with the procedure in Figure 1 may deviate slightly from the true values. The early stage low-temperature phase transformations before the steel is heated to the holding temperature may also affect those compositions, though the present calculations and measurements for the Mn segregation in Steel A (Tables I and II) indicate that the change is small. A long-duration hot-rolling process, however, may considerably affect the soluble compositions, in which case hot-rolled steels cannot be (and were not) included in the optimization process. Evidently, the most reliable CCT equations could be optimized from the measurements of the as-cast steels, because of their simple temperature and event history. Unfortunately, however, not many measurements are readily available.

The second problem is related to the usage of the IDS software only when calculating the soluble compositions for the optimization. It is noteworthy that these compositions remain independent of the austenite decomposition process. For the primary forming phases, this is no problem, but for the secondary phases, like pearlite after ferrite formation, the IDS-calculated soluble compositions are not the same as those obtained by the 
ADC module. However, in the case that the measured start temperature of the secondary phase (applied in the optimization) is not located in the corresponding calculated phase region, the calculated soluble compositions may cause misleading information for the optimization. Therefore, in order to be reasonable, the soluble compositions of the optimization were calculated using the IDS software only.

\section{ACKNOWLEDGMENTS}

Open access funding provided by University of Oulu including Oulu University Hospital. The funding of this research activity under the auspices of the Genome of Steel (Profi3) project by the Academy of Finland through Project \#311934 is gratefully acknowledged.

\section{OPEN ACCESS}

This article is distributed under the terms of the Creative Commons Attribution 4.0 International License (http://creativecommons.org/licenses/by/4.0/), which permits unrestricted use, distribution, and reproduction in any medium, provided you give appropriate credit to the original author(s) and the source, provide a link to the Creative Commons license, and indicate if changes were made.

\section{REFERENCES}

1. J. Trzaska, A. Jagiello, and L.A. Dobrzanski: Arch. Mater. Sci. Eng., 2009, vol. 39 (1), pp. 13-20.

2. J.S. Kirkaldy and D. Venugopalan: Proc. Int. Conf. Phase Transform. Ferr. Alloys, 1983. pp. 125-48.
3. J.S. Kirkaldy: Scand. J. Metall., 1991, vol. 20, pp. 50-61.

4. N. Saunders, Z. Guo, X. Li, A. P. Miodownik, and J.-P. Schille: JMatPro software literature, 2004.

5. F. Liu, C. Yang, G. Yang, and Y. Zhou: Acta Mater., 2007, vol. 55 , pp. 5255-67.

6. J. Miettinen, Helsinki University of Technology Publications in Materials Science and Metallurgy, 1999, pp. 56.

7. J. Miettinen, S. Louhenkilpi, H. Kytönen, and J. Laine: J. Math. Comput. Simulat., 2010, vol. 80, pp. 1536-50.

8. J. Miettinen, S. Louhenkilpi, V.-V. Visuri, and T. Fabritius: IOP Conf. Ser. Mater. Sci. Eng., 2019, vol. 529, p. 012063.

9. S. Louhenkilpi, J. Miettinen, J. Laine, R. Vesanen, I. Rentola, J. Moilanen, V.-V. Visuri, E.-P. Heikkinen, and A. Jokilaakso: IOP Conf. Ser. Mater. Sci. Eng., 2019, vol. 529, p. 012051.

10. K. Hashiguchi, J.S. Kirkaldy, P. Fukuzumi, and V. Pavaskar: CALPHAD, 1984, vol. 8, pp. 173-86.

11. M. Enomoto: ISIJ Int., 1992, vol. 32, pp. 297-305.

12. F. Wever, A. Rose, W. Peter, W. Strassburg, and L. Rademacher: Atlas zur Wärmebehandlung der Stähle, Verlag Stahleisen m.b.H, Düsseldorf, 1961.

13. A. Rose and H. Hougardy: Atlas zur Wärmebehandlung der Stähle, Verlag Stahleisen m.b.H, Düsseldorf, 1972, vol. 2.

14. British Steel Corporation: Atlas of Continuous Cooling Transformation Diagrams for Engineering Steel, British Steel Corporation, Sheffield, 1977.

15. M.C. Somani, J.M. Pyykkönen, D.A. Porter, L.P. Karjalainen, and J.I. Kömi: Mater. Perform. Charact., 2015, vol. 4 (3), pp. 34164. https://doi.org/10.1520/MPC20150001.

16. A. Pohjonen, M. Somani, and D. Porter: Metals, 2018, vol. 8, pp. 540. http://www.mdpi.com/2075-4701/8/7/540.

17. A. Pohjonen, M. Somani, J. Pyykkönen, J. Paananen, and D.A. Porter: Key Eng. Mater., 2016, vol. 716, pp. 368-75. https:// doi.org/10.4028/www.scientific.net/KEM.716.368.

18. A. Pohjonen, A. Kaijalainen, M. Somani, and J. Larkiola: Comput. MethodsMater. Sci., 2017, vol. 17, pp. 30-35.

19. C. Ouchi: ISIJ Int., 2001, vol. 41 (6), pp. 542-53.

20. G.F. van der Voort: Atlas of time-temperature diagrams for irons and steels, ASM International, Cleveland, 1991.

21. J.W. Cahn: Acta Metall., 1956, vol. 4, pp. 572-575.

22. P. Maynier, J. Dollet, and P. Bastien: in Hardenability Concepts with Application to Steel, D.V. Doane and J.S. Kirkaldy, eds., TMS-AIME, Warrendale, 1978, p. 163.

Publisher's Note Springer Nature remains neutral with regard to jurisdictional claims in published maps and institutional affiliations. 